\section{Adaptability and stability of papaya hybrids affected by production seasonality}

\section{Lucas Nunes da Luz ${ }^{1^{*}}$, Renato Santa-Catarina ${ }^{2}$, Gislanne Brito Barros $^{3}$, Fábio Ribeiro Barros ${ }^{4}$, Julio Cesar Fiorio Vettorazzi ${ }^{2}$ and Messias Gonzaga Pereira²}

\begin{abstract}
The present work aimed to estimate the adaptability and stability of new papaya hybrids. The experiments were carried out at the company Caliman Agrícola S/A, in the municipalities of Linhares-ES and Pureza-RN, with seven hybrids from inbred parents of the groups 'Solo' and 'Formosa' and three controls ('Golden', 'Calimosa', and 'Tainung 01'). The experiment consisted of a randomized block design with four replications and ten plants per plot. The variables mean fruit weight (MFW), number of commercial fruits (NCF), and production (PROD) were measured at $270,360,450$, and 540 days after planting. Afterward, the adaptability and stability of the hybrids were estimated using the Lin and Binns, Eberhart and Russell, and Mixed Models. MFW was less affected by the evaluation periods and showed high behavior predictability. The hybrids UC10, UC12, UC14, UC15, and UC16 were the most adapted and predictable and can be recommended for the regions where the experiment took place.
\end{abstract}

Key words: Carica papaya L., solo hybrids, formosa hybrids.

\section{INTRODUCTION}

Papaya has been mostly cultivated between the Southern Bahia and Northern Espírito Santo, with a production of 723.582 and 361.270 ton, respectively, corresponding to $74.11 \%$ of the national production (IBGE 2016). However, the increased demand for the product has required new cultivation areas to supply the domestic and international markets. In a country with continental dimensions such as Brazil, the expansion of cultivation areas is only possible by the development and dissemination of new cultivars, hybrids, and/or varieties adapted to different Brazilian regions.

As a tropical fruit tree, papaya can be sown in all seasons of the year. Its production, which starts at 270 days after planting, remains uninterrupted until the end of the specific cultivation cycle for the crop, which takes three years, on average. In practice, it is known that papaya production, although continuous, is not uniform and may be more intense in summer and less intense in winter. Few studies on this issue are available in the literature; however, some conclusions can be drawn based on studies on papaya floral behavior, since blooming is a determining factor in its production (Silva et al. 2007a, Damasceno Júnior et al. 2008).

The appearance of imperfect flowers in hermaphrodite papaya plants is
Crop Breeding and Applied Biotechnology 18: 357-364, 2018 Brazilian Society of Plant Breeding. Printed in Brazil http://dx.doi.org/10.1590/1984$70332018 v 18 n 4 a 54$

\author{
*Corresponding author: \\ E-mail: lucasluz@unilab.edu.br \\ Received: 25 October 2016 \\ Accepted: 11 May 2017
}

\footnotetext{
${ }^{1}$ Universidade da Integração Internacional da Lusofonia Afro-Brasileira, Instituto de Desenvolvimento Rural, 62.790-000, Redenção, CE, Brazil

${ }^{2}$ Universidade Estadual do Norte Fluminense Darcy Ribeiro, 28.013-602, Campos dos Goytacazes, RJ, Brazil

${ }^{3}$ Universidade Federal do Piauí, Campus Senador Helvídio Nunes de Barros, 64.600000, Bairro Junco, Picos, PI, Brazil ${ }^{4}$ Universidade Estadual do Maranhão, Centro de Estudos Superiores de Balsas, 65.800-000, Balsas, MA, Brazil
} 


\section{LN Luz et al.}

associated with genetic effects, which are affected by environmental factors, such as high humidity and high levels of nitrogen and water in the soil (Almeida et al. 2003). Silva et al. (2007a) and Damasceno Júnior et al. (2008) evaluated floral behavior in hybrids and elite genotypes and reported that variation in the number of perfect hermaphrodite flowers, which bear commercial standard fruits, is higher in the summer, when the number of sterile flowers increases and fewer fruits are produced. This phenomenon, known as summer sterility (Storey 1958), is one of the main causes of decreased production in some periods of the year, since it concentrates production in certain seasons.

Martelleto et al. (2011) carried out an experiment to compare fruiting in a variety of papaya in different seasons of the year, under greenhouse and field conditions, and estimated the number of carpelloid, pentandric, and normal (commercial) fruits. The data obtained by these authors corroborate the reports of Silva et al. (2007a) and Damasceno Júnior et al. (2008) on increased sterility and increased number of deformed fruits in different seasons of the year. This indicates that production can significantly fluctuate when measured in different seasons, depending on the environmental conditions.

The recommendation of superior genotypes, hybrids, or varieties for cultivation in different regions must meet the minimum criteria that enable inferring about the genotype potential in the cultivation environment. Adaptability and stability, which are the responsiveness of genotype to an improved environment and the predictability of genotype behavior (Cruz et al. 2013), respectively, are the main parameters of reliability in genotype behavior prediction. Several methods can be used to estimate these parameters, including those based on the analysis of variance (Plaisted and Peterson 1959), regression (Finlay and Wilkinson 1963, Eberhart and Russell 1966), mixed models (Resende and Duarte 2007), and more modern methods that combine multivariate analysis techniques, such as AMMI - Additive main effects and multiplicative interaction analysis (Annicchiarico 1997), the Bayesian method proposed by Nascimento et al. (2011), and the artificial neural networks for adaptability and stability evaluation in alfalfa genotypes, proposed by Nascimento et al. (2013).

In annual species, genotype behavior prediction in growing environments is commonly estimated for different cultures using different methodologies. However, the assessment of perennial or semiperennial plants, including papaya, is more difficult. In the case of papaya, fruit production occurs throughout the cycle, being concentrated in specific periods of the year. Under such conditions, coefficients of adaptability and stability can be incorrectly estimated since production fluctuation is common in some periods. Therefore, in papaya, genotypes behavior should be estimated per evaluation season, which refers to an estimated behavior per periods of production or harvest.

In this study, the coefficients of adaptability and stability coefficients for the traits (number of commercial fruits, mean fruit weight, and production) were estimated and compared in production cycles in new hybrids of papaya as they were released. This comparison was carried out by different methods of analysis, aiming at a better interpretation of the results for production fluctuation between production seasons in papaya cultivation.

\section{MATERIAL AND METHODS}

Experiments were carried out in two regions of papaya production. The first was located in Linhares-ES, in Santa Terezinha Farm, which belongs to the company Caliman Agrícola S/A (lat 19o 23' S, long 40 04' W, alt 33 m asl), with average annual temperature of $23.4^{\circ} \mathrm{C}$ and average rainfall of $1193 \mathrm{~mm}^{\circ}$ ear ${ }^{-1}$. The second environment is located in Pureza-RN, in the sub-office of the company Caliman Agrícola S/A (lat $05^{\circ} 28^{\prime} \mathrm{S}$, long $35^{\circ} 33^{\prime} \mathrm{W}$, alt $40 \mathrm{~m}$ asl).

Seven papaya hybrids from the UENF/Caliman joint breeding program were evaluated. The hybrids were developed in the seed production sector of the company Caliman Agrícola S/A, in Santa Terezinha Farm, in Linhares-ES, from inbred parents preserved in the UENF/Caliman germplasm bank. Hybrid combinations were defined in previous diallel trials carried out by Marin et al. (2006a, b), Ide et al. (2009), and Cardoso et al. (2015).

Hybrids were obtained from parents belonging to the heterotic groups 'Solo' and 'Formosa'. Thus, the hybrids UC13, UC14, UC15, and UC16 were obtained from Solo x Solo hybridizations; the hybrids UC03 and UC10 were obtained from hybridization within the Formosa group; and the triple hybrid UC12 was obtained from the cross between a simple

Formosa $x$ Solo hybrid and a Formosa parent, and therefore, it fits in the hybrid category of the Formosa group. The variety 'Golden' and the hybrids 'Calimosa' and 'Tainung 01 ' were used as controls. 
Hybrid seeds were placed in plastic tubes for germination, in a greenhouse in Santa Terezinha Farm. After germination, the seedlings remained in the greenhouse for 20 days. Then, they were acclimatized outside the greenhouse. The same procedure was carried out in Caliman Agrícola sub-office, in Pureza-RN, where the experiments were implanted.

At 30 days after germination, seedlings were planted in the field. The experiment was arranged in a randomized block design with four replications, spaced at $1.5 \times 3.6 \mathrm{~m}\left(5.4 \mathrm{~m}^{2}\right.$ plant $\left.{ }^{-1}\right)$ between plants, in single rows, with ten plants per plot.

Field data were collected from harvests carried out at 270,360, 450, and 540 days after planting in each study environment. The following variables were measured: mean fruit weight - MFW ( $\mathrm{kg})$, measured by the mean of five fruits in the plot; Number of commercial fruits - NCF obtained by the counting of the number of fruits per plant in each evaluation period, excluding the fruits that did not meet the commercial standard; and Production - PROD $\left(\mathrm{kg} \mathrm{plant}^{-1}\right)$, calculated by the product between the number of commercial fruits per plant and the mean fruit weight.

Data were subjected to the Shapiro-Wilk normality test for quality evaluation. For the homogeneity test, residual variance of each environment was evaluated by the ratio between the largest residual mean square and the lowest residual mean square. According to Pimentel-Gomes (1990), variances are considered as homogeneous if this ratio is lower than seven; in this case, joint analysis of variance can be performed to evaluate seasons and cultivation environments.

Analysis of variance was performed according to the model: $Y_{i j k}=\mu+G_{i}+B / A_{j k}+A_{j}+G A_{i j}+\varepsilon_{i j k}$, where $Y_{i j k}$ is the observed value of genotype i in block $k(k=1,2, \ldots, r)$ and within environment $j ; \mu$ is the overall mean of the trials; $G_{i}$ is the fixed effect of genotype $i$, with $i=1,2,3, \ldots, p ; B / A_{j k}$ is the effect of block $k$ within environment $j ; A_{j}$ is the random effect of environment $\mathrm{j}$, with $\mathrm{j}=1,2,3, \ldots, \mathrm{q} ;(G A)_{i j}$ is the fixed effect of genotype $\mathrm{i}$ x environment $\mathrm{j}$ interaction; $\varepsilon_{i j k}$ is the experimental error. Afterward, the joint analysis of variance and mean comparison were performed using the SAS Studio software system (SAS Institute, Cary, NC, USA). Based on the data of the eight harvests of this study (four seasons in each environment), adaptability and stability of the hybrids were evaluated for the traits, using three different methods: Lin and Binns (1988), Eberhart and Russel (1966), and Mixed Models (Resende 2007, Gonçalves and Fritsche-Neto 2012, Cruz et al. 2013).

The non-parametric analysis of adaptability and stability, according to the method proposed by Linn and Binns (1988), is based on the index $\mathrm{Pi}=\Sigma\left(\mathrm{Yij}_{\mathrm{ij}}-\mathrm{Mi}\right)^{2} / 2 n$, where $\mathrm{P}_{\mathrm{i}}$ is the estimate of the stability index of genotype $i ; Y_{i j}$ is the behavior of genotype $i$ in environment $j ; M_{j}$ is the maximal response observed among all genotypes in environment $j$; and $n$ is the number of environments. The $P_{i}$ index indicates the stability of a genotype, and the lower the value of $P_{i}$ index, the more stable is the material.

The Eberhart and Russell (1966) method is based on the linear regression obtained by $Y_{i j}=\mu+b_{i j} I_{i j}+\varepsilon_{i j}$, where $Y_{i j}$ is the behavior of genotype $i$ in environment $j ; \mu$ is the general mean; $\beta_{i}$ is the coefficient of linear regression; $I_{j}$ is the environmental index; $\delta_{\mathrm{ij}}$ is the deviation of the regression of genotype $\mathrm{i}$ in environment $\mathrm{j}$; and $\delta_{\mathrm{ij}}$ is the error associated with the mean. According to this model, the adaptability of a genotype is estimated by its regression coefficient $\left(\beta_{i}\right)$ in relation to the environmental index $\left(\mathrm{I}_{\mathrm{j}}\right)$ in each environment, and the stability is estimated by the variance of the deviations of $\sigma^{2}{ }_{\mathrm{di}}$ regression. Therefore, genotypes with $\beta$ i equal to 1 are considered as adapted; and genotypes with $\sigma_{\mathrm{di}}^{2}$ and not significantly different from zero by the Tukey test are considered as stable.

In the mixed models methodology, the components of variance were estimated by the REML/BLUP procedure, according to the model $Y=X_{r}+Z_{g}+W_{i}+e$, where $\mathrm{y}$ is the data vector; $r$ is the vector of replication effects (assumed as fixed) added to the overall mean; $g$ is the vector of genotypic effects (assumed as random); $i$ is the vector of the effects of the genotype $\times$ environment interaction (random); e is the vector of errors or residues (random); and the capital letters are the incidence matrices for these effects. Analyses of adaptability and stability were performed considering the model 54 (Complete block design in several environments and one observation per plot - MHPRVG Method) (Resende 2016).

\section{RESULTS AND DISCUSSION}

Significant interaction was observed between genotypes for all traits evaluated, as well as for period $\times$ harvest environment, except for the genotype $\times$ environment interaction for the trait mean fruit weight (Table 1). These significant interactions show that fruit production is strongly affected by the season of the year and planting environment and that 
Table 1. Analysis of variance for three traits in papaya hybrids evaluated in two environments, Pureza-RN and Linhares-ES, in eight seasons

\begin{tabular}{lcccc}
\hline \multirow{2}{*}{ Sources of variation } & df & \multicolumn{3}{c}{ Mean Squares } \\
\cline { 3 - 5 } & & NCF & MFW & PROD \\
\hline Blocks/PE & 24 & $256.131^{* *}$ & $0.057^{*}$ & $236.465^{* *}$ \\
Environment (E) & 1 & $1604.288^{* *}$ & $0.104^{*}$ & $1943.751^{* *}$ \\
Periods (P) & 3 & $6409.909^{* *}$ & $0.342^{* *}$ & $7701.139^{* *}$ \\
E*P & 3 & $1704.787^{* *}$ & $1.076^{* *}$ & $1254.298^{* *}$ \\
Genotypes (G) & 9 & $1368.776^{* *}$ & $6.777^{* *}$ & $1095.412^{* *}$ \\
G*E & 9 & $74.803^{*}$ & 0.024 & $111.345^{*}$ \\
G*P & 27 & $113.163^{* *}$ & $0.064^{* *}$ & $142.248^{* *}$ \\
E*G*P & 27 & $165.199^{* *}$ & $0.070^{* *}$ & $246.476^{* *}$ \\
Error & 216 & 28.490 & 0.024 & 31.574 \\
Mean & - & 24.29 & 1.11 & 25.15 \\
CV (\%) & & 21.79 & 13.91 & 22.34 \\
\hline
\end{tabular}

NCF: number of commercial fruits; MFW: mean fruit weight in kg and PROD: production per period in $\mathrm{kg} \mathrm{plant}^{-1}$.

this effect, which can be defined as production seasonality, must be well understood when comparing production rates in different environments and seasons.

Moreover, Table 1 shows that the genetic component, highlighted in the mean square of the genotype, overlaps the residue, which indicates that variation is mainly due to genetics. The experiment precision measured by the coefficient of variation is consistent with that expected from a field experiment (Costa et al. 2002). Furthermore, all the traits presented in Table 1 showed normality and demonstrated that the joint analysis of the experiments was obtained after confirming the error variances homogeneity.

Table 2 shows an estimate of the mean production of the period for the hybrids evaluated. The number of NCF per plant varied widely among hybrids and controls. UC14 was the best in the production rank, and the hybrid 'Tainung 01' was the worst. Differently, for production or yield, hybrid UC10 was superior to the others on average, and the variety 'Golden' showed the worst performance. However, it presented superior performance for the number of commercial fruits. This is because the mean fruit weight of the variety 'Golden' is only $0.466 \mathrm{~kg}$. In terms of production, considering the mean of the seasons, the hybrids of the 'Solo' group, especially UC14, UC15, and UC16, are as productive as the control 'Calimosa', which is a hybrid originated from the Solo $\times$ Formosa group, superior to the control 'Golden' and to the control 'Tainung 01' (in the case of UC14).

Despite the contribution of the knowledge of the mean for the mentioned traits, they should not be taken as properties that completely describe the set of hybrids since they depend on the experiment, that is, they represent the mean of the evaluation periods, rather than the mean of each individual period, in which the positions would certainly be changed.

Table 3 shows the values of general stability coefficients (Pi) calculated by the nonparametric method of Lin and Binns (1988). For NCF, a tendency for greater production stability (lowest Pi values) was observed in the seasons for the genotypes from the 'Solo' group (from the largest to the smallest: UC14, 'Golden', UC15, UC16, and UC13). This means, for instance, that during the production cycle, UC14, the best-ranked genotype, produces fruits regularly at any season, depending, of course, on growth conditions. UC14 is also considered as the most stable genotype in both favorable $(\mathrm{P}+)$ and unfavorable ( $\mathrm{P}-$ ) environments, which

Table 2. Means for the traits evaluated in the set of environments and seasons

\begin{tabular}{lcll}
\hline \multirow{2}{*}{ Genotypes } & \multicolumn{3}{c}{ Means } \\
\cline { 2 - 4 } & NCF & MFW & PROD \\
\hline UC03 & $16.82 \mathrm{c}$ & $1.390 \mathrm{c}$ & $23.40 \mathrm{cb}$ \\
UC10 & $17.70 \mathrm{c}$ & $1.930 \mathrm{a}$ & $35.11 \mathrm{a}$ \\
UC12 & $23.18 \mathrm{~b}$ & $1.340 \mathrm{c}$ & $31.65 \mathrm{a}$ \\
UC13 & $24.09 \mathrm{~b}$ & $0.832 \mathrm{fe}$ & $19.89 \mathrm{c}$ \\
UC14 & $34.68 \mathrm{a}$ & $0.777 \mathrm{f}$ & $26.93 \mathrm{~b}$ \\
UC15 & $26.75 \mathrm{~b}$ & $0.913 \mathrm{e}$ & $24.35 \mathrm{cb}$ \\
UC16 & $25.71 \mathrm{~b}$ & $0.929 \mathrm{e}$ & $24.61 \mathrm{~b}$ \\
'Golden' & $34.06 \mathrm{a}$ & $0.390 \mathrm{~g}$ & $13.78 \mathrm{~d}$ \\
'Calimosa' & $24.17 \mathrm{~b}$ & $1.090 \mathrm{~d}$ & $26.70 \mathrm{~b}$ \\
'Tainung 01' & $15.75 \mathrm{c}$ & $1.550 \mathrm{~b}$ & $25.09 \mathrm{~b}$ \\
\hline
\end{tabular}

Means followed by the same letter in the column were not significantly different $(p<0.05)$ by the Tukey's test. NCF: number of commercial fruits; MFW: mean fruit weight in $\mathrm{kg}$; and PROD: Total production in $\mathrm{kg}^{\text {plant }}{ }^{-1}$. 
reflects the plasticity of this hybrid in the production seasons.

Conversely, concerning the relationship observed between the genotypes from the 'Formosa' group as a whole, UC03, UC12, UC10, and 'Tainung 01' were the least stable for fruit production over the seasons. This fact confirms, to some extent, the phenomenon observed in the field, in which the genotypes of the 'Formosa' group presented great fruit load in the first months of production and a sharp decline in the last harvests. This was observed for all genotypes of the 'Formosa' group, in both environments. Among the hybrids of the 'Formosa' group, the least sharp production decline occurred exactly with the hybrid UC12, the best Formosa group genotype for stability (Table 3). However, the opposite was reported for MFW, since the hybrids from the 'Formosa' group were the most stable, not only in general but also in favorable and unfavorable environments.

The variable PROD is obtained by multiplying the mean fruit weight and the number of commercial fruits produced by the plant in the period. Table 3 shows that the hybrids UC10, UC12, and 'Calimosa' were more stable for production. The Lin and Binns (1988) method is very practical for allowing the direct evaluation of the results, although it only quantifies stability and gives no measure for adaptability. The method is widely used in several works, and often presents a high

Table 3. Stability by the Lin and Binns model (1988)

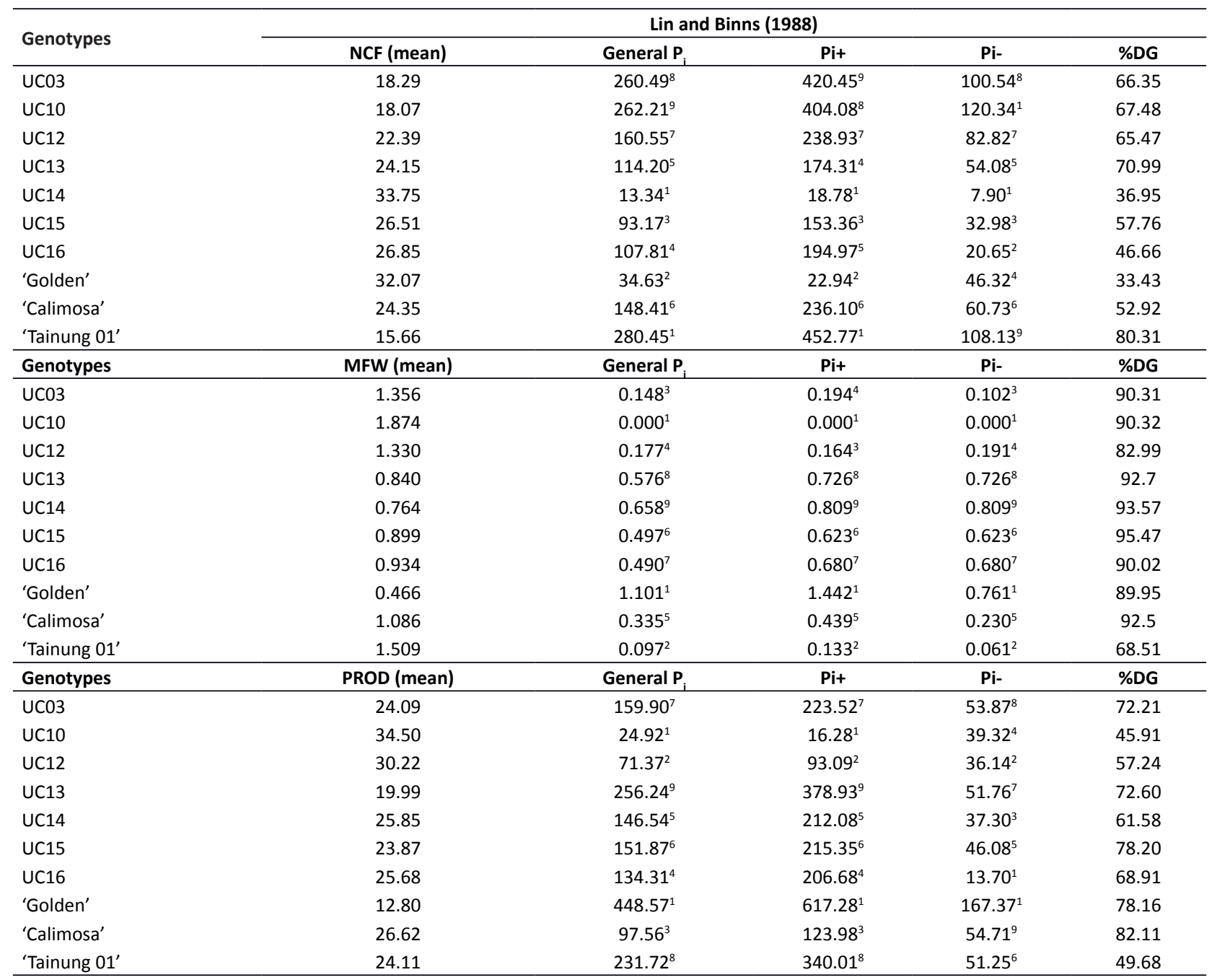

Pi: general stability mean; Pi+: stability at favorable environments; Pi: stability at unfavorable environments; \%DG: contribution of the genetic deviation for interaction; NCF: number of commercial fruits; MFW: mean fruit weight in $\mathrm{kg}$; and PROD: production per period in $\mathrm{kg} \mathrm{plant}^{-1}$. 
correlation with more robust methods, such as that of Eberhart and Russel (1966), among others (Elias et al. 2006, Silva and Duarte 2006, Pereira et al. 2009, Scapim et al. 2010).

The adaptability and stability coefficients were also estimated by the Eberhart and Russell method (1966), which is very robust and often used in various crops, such as in papaya (Yang et al. 2011, Oliveira et al. 2014), peanuts (Oliveira and Godoy 2006, Gomes et al. 2007), and popcorn (Scapim et al. 2010). The method has shown its effectiveness in relation to other methods (Elias et al. 2006, Pereira et al. 2009, Silva and Duarte 2006).

The results obtained by the Eberhart and Russell (1966) method, shown in Table 4, for the trait NCF, revealed that all genotypes had broad adaptability, except for UC14, 'Golden', and 'Tainnung 01'). This means that they had broad adaptability to all harvest seasons, being UC13 and UC15 adapted to favorable environments. Regarding the behavior predictability, only UC15 was stable. For the MFL, only UC10 and 'Golden' were not adapted, which in fact is rather consistent. These genotypes showed the highest and the lowest mean for MFW and NCF, respectively, due to the strong negative correlation between weight and number of fruits in papaya (Silva et al. 2007b, Oliveira et al. 2014) and may lead to variation over the harvest seasons.

Regarding the trait production, only UC10 and 'Golden' were not adapted. On the other hand, only UC15 and 'Calimosa' presented stability in the evaluation periods, besides adaptation. Table 4 also shows that despite presenting wide adaptation, UC03, UC12, UC13, UC14, and UC16 are considered as unstable. This might be due to the different

Table 4. Adaptability and stability by the Eberhart and Russell regression model (1966)

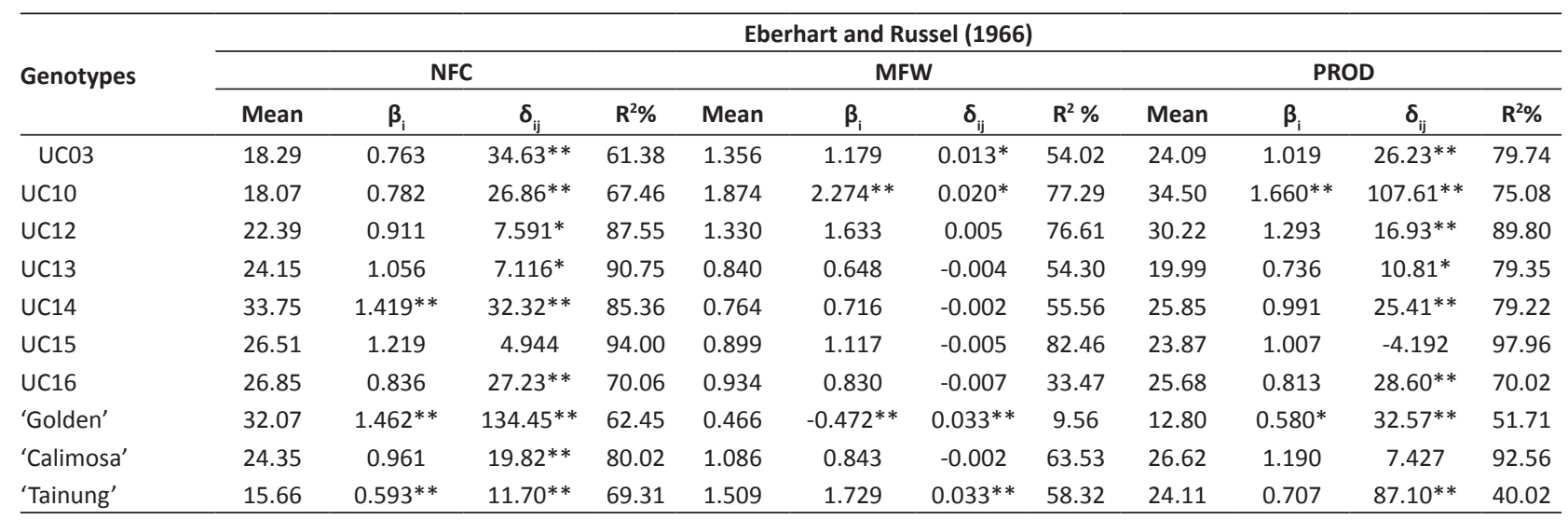

$\beta_{i}^{*}$ and ** differs from one, at 5 and $1 \%$ probability by the Tukey's test, respectively. $\delta_{i j}^{*}$ and ** differs from zero, at 5 and $1 \%$ probability by the $\mathrm{F}$ test, respectively. NCF: number of commercial fruits; MFW: mean fruit weight in $\mathrm{kg}$; and PROD: production per period in $\mathrm{kg} \mathrm{plant}^{-1}$.

Table 5. Adaptability and stability based on individual genotypic values for three production traits in papaya

\begin{tabular}{|c|c|c|c|c|c|c|c|c|c|}
\hline \multirow{2}{*}{ Genotype } & \multicolumn{3}{|c|}{ NCF } & \multicolumn{3}{|c|}{ MFW } & \multicolumn{3}{|c|}{ PROD } \\
\hline & MHV & PRV & MHPRVG & MHV & PRV & MHPRVG & MHV & PRV & MHPRVG \\
\hline UCO3 & 10.08 & 16.04 & 15.21 & 1.21 & 4.63 & 4.63 & 15.69 & 22.78 & 22.31 \\
\hline UC12 & 17.87 & 23.42 & 23.03 & 1.20 & 4.62 & 4.62 & 23.78 & 31.89 & 31.38 \\
\hline UC13 & 19.00 & 24.30 & 24.01 & 1.16 & 4.48 & 4.48 & 14.90 & 20.23 & 19.84 \\
\hline UC14 & 27.69 & 35.33 & 34.74 & 1.16 & 4.47 & 4.47 & 19.77 & 27.35 & 26.63 \\
\hline UC16 & 20.50 & 26.30 & 25.99 & 1.17 & 4.51 & 4.51 & 18.13 & 24.84 & 24.59 \\
\hline 'Golden' & 26.96 & 34.66 & 33.69 & 1.13 & 4.37 & 4.36 & 8.68 & 13.70 & 12.97 \\
\hline 'Calimosa' & 18.03 & 24.16 & 23.66 & 2.14 & 8.06 & 8.03 & 18.97 & 26.32 & 25.94 \\
\hline 'Tainung' & 9.52 & 15.41 & 14.50 & 1.22 & 4.68 & 4.68 & 16.77 & 25.45 & 23.75 \\
\hline
\end{tabular}

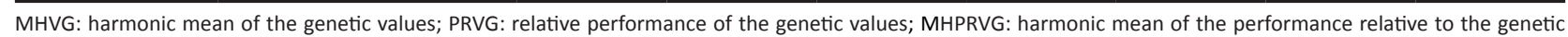
values; NCF: number of commercial fruits; MFW: mean fruit weight in kg; and PROD: production per season in $\mathrm{kg}^{\mathrm{p}} \mathrm{plant} \mathrm{t}^{-1}$. 
fruiting rate in the seasons, that is, the gap in the periods of maximum plant load. Conversely, UC03, UC10, UC12, and UC15 showed adaptability to favorable environments, that is, environments whose $\beta 1$ magnitude is superior to the unity, although UC13, UC14, and UC16, which are hybrids from the 'Solo' group, showed adaptation to unfavorable environments, with $\beta 1$ lower than the unity. Thus, it is inferred that in environments where the standard required for cultivation are more difficult to be maintained, hybrids from the 'Formosa' group tend to accumulate more production losses than hybrids from the 'Solo' group. This actually occurs, and these hybrids are more affected by summer sterility than those of the 'Solo' group.

Table 5 describes the harmonic mean of the genetic values (MHVG), the stability measurement, the relative performance of the genetic values (PRVG), the stability measurement, and the combination with the harmonic mean of the performance related to the genetic values (MHPRVG), which includes adaptability and stability. For NCF, the result of Table 5 highlights the genotypes UC13, UC14, UC16, and 'Golden', that is, hybrids from the 'Solo' group. This is consistent with the results obtained by the Lin and Binns (1988) method, discussed in Table 3. UC03, UC12, UC16, and 'Calimosa' stand out for MFW, which corroborates the results in Table 3.

In general, for the trait production, hybrids UC10 and UC12 from the 'Formosa' group, and hybrids UC14 and UC16, from the 'Solo' group, presented the best MHPRVG estimates. In other words, they showed wide adaptability and predictable behavior over the harvests. Regarding the hybrids from the 'Formosa' group, these results are similar to those obtained the by Lin and Binns (1988) method, and generally different from those provided by the Eberhart and Russell (1966) method.

Mean fruit weight is the least affected trait by the evaluation periods, with high behavior predictability. Hybrids UC10, UC12, UC14, UC15, and UC16 are among the most adapted and predictable in the set of hybrids evaluated in this study. This behavior regarding the evaluation seasons indicates that these genotypes can be recommended for several regions, including the semi-arid area and the region of Linhares-ES, where the hybrids were evaluated. The non-exact agreement between the methods and the occurrence of high adaptability in the hybrids, with low predictability in some cases, should be understood as a result of the specificity of each method employed and the seasonal crop production, resulting from the behavior of each hybrid and environmental conditions.

\section{REFERENCES}

Almeida JCS, Marinho CS, Souza EF and Grippa S (2003) Sexual expression of papaya tree affected by depth of irrigation in the north region of Rio de Janeiro, Brazil. Revista Brasileira de Fruticultura 25: 383-385.

Annicchiarico P (1997) Additive main effects and multiplicative interaction (AMMI) analysis of genotype-location interaction in variety trials repeated over years. Theoretical and Applied Genetics 94: 10721077.

Cardoso DL, Vivas M, Amaral Júnior AT and Pereira MG (2015) Análise dialélica de Hayman de características relacionadas à produção e a qualidade de frutos em mamoeiro. Bragantia 74: 394-399.

Costa NHAD, Seraphin JC and Zimmermann FJP (2002) Novo método de classificação de coeficientes de variação para a cultura do arroz de terras altas. Pesquisa Agropecuária Brasileira 37: 243-249.

Cruz CD, Regazzi AJ and Carneiro PCS (2013) Diversidade genética. In Cruz CD (ed) Modelos biométricos aplicados ao melhoramento de plantas. UFV, Viçosa, p. 392-429.

Damasceno Júnior PC, Pereira TNS, Silva FF, Viana AP and Pereira MG (2008) Comportamento floral de híbridos de mamoeiro (Carica papaya L.) avaliados no verão e na primavera. Ceres 55: 310-316.

Eberhart SA and Russel WA (1966) Stability parameters for comparing varieties. Crop Science 6: 36-40.

Elias HT, Hemp S, Scapim CA, Rodovalho MA, Royer MR, Mora F and Barreto RR (2006) Análise de estabilidade de genótipos de feijoeiro no Estado de Santa Catarina. Acta Scientiarum Agronomy 27: 623-628.

Finlay KW and Wilknson GN (1963) The analysis of adaptation in a plantbreeding program. Australian Jornal of Agriculture Research 14: 742-754

Gomes LR, Santos RC, Anunciação Filho CJ and Melo Filho PA (2007) Adaptabilidade e estabilidade fenotípica de genótipos de amendoim de porte ereto. Pesquisa Agropecuária Brasileira 42: 985-989.

Gonçalves MC and Fritsche-Neto R (2012) Tópicos especiais em biometria no melhoramento de plantas. Editora Suprema, Visconde do Rio Branco, p. 282.

IBGE - Instituto Brasileiro de Geografia e Estatística (2016) Áreas destinadas a colheita e rendimento médio. Avaliable at <http://www. ibge.gov.br>. Acessed on March 7, 2017.

Ide CD, Pereira MG, Viana, AP and Pereira TNS (2009) Use of testes for combining ability and selection of papaya hybrids. Crop Breeding and Applied Biotechnology 9: 60-66.

Lin CS and Binns MR (1988) Superiority measure of cultivar performance for cultivar $\mathrm{x}$ environment data. Canadian journal of plant science 


\section{LN Luz et al.}

68: $193-198$.

Marin SLD, Pereira MG, Amaral Júnior AT, Martelleto LAP and Ide CD (2006a) Heterosis in papaya hybrids from partial diallel of 'Solo' and 'Formosa' parents. Crop Breeding and Applied Biotechnology 6: 24-29.

Marin SLD, Pereira MG, Amaral Júnior AT, Martelleto LAP and Ide CD (2006b) Partial diallel to evaluated the combining ability for economically important traits of papaya. Scientia Agricola 63: 540-546.

Martelleto LAP, Ribeiro RLD, Sudo-Martelleto M, Vasconcelos MAS and Pereira MB (2011) Expressão da esterilidade feminina e da carpeloidia em mamoeiro sob diferentes ambientes de cultivo protegido. Revista Brasileira de Fruticultura 33: 1185-1193.

Nascimento M, Silva FF, Sáfadi T, Nascimento ACC, Ferreira RP and Cruz CD (2011) Abordagem bayesiana para avaliação da adaptabilidade e estabilidade de genotypes de alfafa. Pesquisa Agropecuária Brasileira 46: 26-32.

Nascimento M, Peternelli LA, Cruz CD, Nascimento ACC, Ferreira RP, Bhering LL and Salgado CC (2013) Artificial neural networks for adaptability and stability evaluation in alfalfa genotypes. Crop Breeding and Applied Biotechnology 13: 152-156.

Oliveira EJ and Godoy IJ (2006) Pod yield stability analysis of runner peanut lines using AMMI. Crop Breeding and Applied Biotechnology 6: 311-317.

Oliveira EJ, Fraife Filho GA, Freitas JPX and Dantas JLL (2014) Desempenho produtivo e interação genótipo $\mathrm{x}$ ambiente em híbridos e linhagens de mamoeiro. Bioscience Journal 2: 402-410.

Pereira HS, Melo LC, Del Peloso MJ, Faria LC, Costa JGC, Díaz JC and Wendland A (2009) Comparação de métodos de análise de adaptabilidade e estabilidade fenotípica em feijoeiro-comum. Pesquisa Agropecuária Brasileira 44: 374-383.

Pimentel-Gomes F (1990) Curso de estatística experimental. $13^{\text {th }}$ edn,
Nobel, Piracicaba, 468p.

Plaisted RL and Peterson LC (1959) A technique for evaluating the ability of selections to yield consistently in different environments and seasons. American Potato Journal 39: 381-385.

Resende MDV (2016) Software Selegen-Reml/Blup. Crop Breeding and Applied Biotechnology 16: 330-390.

Resende MDV (2007) Selegen-Reml/Blup: Sistema estatístico e seleção genética computadorizada via modelos lineares mistos. Embrapa Florestas, Colombo, 360p.

Resende MDV and Duarte JB (2007) Precisão e controle de qualidade em experimentos de avaliação de cultivares. Pesquisa Agropecuária Tropical 37: 182-194.

Scapim CA, Pacheco CAP, Amaral Júnior AT, Vieira RA, Pinto RJB and Conrado TV (2010) Correlations between the stability and adaptability statistics of popcorn cultivars. Euphytica 174: 209-218.

Silva WCJ and Duarte JB (2006) Métodos estatísticos para estudo de adaptabilidade e estabilidade fenotípica em soja. Pesquisa Agropecuária Brasileira 41: 23-30.

Silva FF, Pereira MG, Damasceno Júnior PC, Pereira TNS, Viana AP, Daher RF and Ferreguetti GA (2007a) Evaluation of the sexual expression in a segregating $\mathrm{BC}$ papaya population. Crop Breeding and Applied Biotechnology 7: 16-23.

Silva FF, Pereira MG, Ramos HCC, Damasceno Junior PC, Pereira TNS and Ide CD (2007b) Genotypic correlation of morpho-agronomic traits in papaya and implications for genetic breeding. Crop Breeding Applied Biotechnology 7: 345-352.

Storey WB (1958) Modifications of sex expression in papaya. Horticulture Advances 2: 49-60.

Yang W, Quing-xi C and Yu-fang L (2011) Cultivation and adaptability of Papaya species from Taiwan in Zhangzhou area. Fujian Journal of Agricultural Sciences 1: 83-86.

(cc) $\mathrm{EY}$ This is an Open Access article distributed under the terms of the Creative Commons Attribution License, which permits unrestricted use, distribution, and reproduction in any medium, provided the original work is properly cited. 